\title{
HUBUNGAN KONSEP DIRI, SIKAP GURU TERHADAP PEKERJAAN \\ DAN PENGALAMAN MENJADI GURU DENGAN KEMAMPUAN MENGAJAR GURU DI SMP NEGERI DI KOTA PALANGKA RAYA
}

\author{
SONEDI \\ Dosen Program Studi Pendidikan Ekonomi Fakultas Keguruan dan Ilmu Pendidikan \\ Universitas Muhammadiyah Palangkaraya
}

\begin{abstract}
These results showed that : (1) there is a significant correlation between self-concept and the ability of teachers to teach in the State Junior High School in Palangka Raya, amounting to 35.9\%; (2) the results of research on teacher attitudes towards work gives a significant correlation with the teachers' teaching ability. Teacher attitudes toward work are able to contribute to the teaching capabilities of teachers by 41.2\%; (3) the experience of being a teacher giving a significant correlation to the ability of teachers to teach. The experience of being a teacher is able to explain the ability of teachers to teach at $39.3 \%$. (4) there is a significant correlation between self-concept, attitude towards the work of teachers, and the teachers' teaching experience in State Junior High School in Palangkaraya. These three independent variables jointly contribute significantly to the ability of teachers to teach, especially in this study amounted to $58.3 \%$. (5) There is a correlation between the variables self-concept, attitudes of teachers towards work and experience as a teacher with the ability of teachers to teach. Variable attitude of teachers towards work $(41.2 \%)$, is the most dominant variable related to the ability of teachers to teach.
\end{abstract}

Keywords: self-concept, attitude towards the work of teachers, teaching experience and teaching skills of teachers

\begin{abstract}
ABSTRAK
Hasil penelitian ini menunjukan bahwa : (1) ada hubungan yang signifikan antara konsep diri dengan kemampuan mengajar guru di SMP Negeri Palanga Raya, sebesar 35.9\%; (2) hasil penelitian tentang sikap guru terhadap pekerjaan memberikan hubungan yang signifikan dengan kemampuan mengajar guru. Sikap guru terhadap pekerjaan mampu memberikan sumbangan terhadap kemampuan mengajar guru sebesar $41.2 \%$; (3) pengalaman menjadi guru memberikan hubungan yang signifikan terhadap kemampuan mengajar guru. Pengalaman menjadi guru mampu menjelaskan kemampuan mengajar guru sebesar $39.3 \%$. (4) ada hubungan yang signifikan antara konsep diri, sikap guru terhadap pekerjaan, dan pengalaman mengajar guru SMP Negeri di Kota Palangka Raya. Ketiga variabel bebas tersebut secara bersama-sama memberi sumbangan yang signifikan dengan kemampuan mengajar guru khususnya dalam penelitian ini sebesar $58.3 \%$. (5) ada perbedaan hubungan diantara variabel konsep diri, sikap guru terhadap pekerjaan dan pengalaman menjadi guru dengan kemampuan mengajar guru. Variabel sikap guru terhadap pekerjaan $(41.2 \%)$, merupakan variabel yang paling dominan hubungannya terhadap kemampuan mengajar guru.
\end{abstract}

Kata kunci : konsep diri, sikap guru terhadap pekerjaan, pengalaman mengajar dan kemampuan mengajar guru

\section{PENDAHULUAN}

Perkembangan pendidikan dewasa ini pada umumnya telah menunjukkan kemajuan, baik secara kuantitatif maupun kualitatif. Peningkatan mutu sistem pendidikan secara menyeluruh menuntut antara lain upaya sistemik dalam hal persiapan, pembinaan, dan pengembangan kompetensi sejumlah besar guru dan kepala sekolah, untuk dapat menjamin terselenggaranya program pendidikan yang berkualitas. (Kasinu, 
2006: 120) Hal ini akan memungkinkan mereka menjalankan fungsinya secara efektif dalam menyelenggarakan dan mengembangkan proses pembelajaran yang relevan dan tanggap terhadap kebutuhan individu dan masyarakat yang senantiasa berubah (Salamah, 2004: 46).

Kualitas dan keberadaan sekolah menjadi sangat penting untuk diperhatikan sebagai strategi pengembangan sumber daya manusia (SDM). Oleh karena itu, dalam rangka peningkatan SDM, pendidikan menempati posisi yang amat strategis. Kualitas dan kuantitas pendidikan yang ada akan menentukan ketersediaan SDM. Sumber daya manusia yang berkualitas hanya akan lahir dari pendidikan yang berkualitas. Pemerintah secara terus menerus berupaya untuk meningkatkan kualitas pendidikan lewat berbagai program pembaruan. Pada saat ini tidak dapat dipungkiri bahwa kemajuan ilmu pengetahuan dan teknologi semakin berkembang. Salah satu faktor yang kurang diperhitungkan secara cermat yaitu kecenderungan kehidupan berubah cepat dibandingkan dengan pendidikan yang disediakan. Menurut Engkoswara (2005: 3031) keadaan ini akan lebih baik bila pendekatan yang berlaku sekarang disempurnakan dengan memberikan tekanan pada pendidikan menjadi kekuatan utama untuk jangka panjang jauh ke depan, dalam dimensi kehidupan. $\mathrm{Hal}$ ini memerlukan banyak inovasi dalam bidang teknologi pendidikan. Adapun kepedulian teknologi pendidikan dalam proses pengajaran menurut Miarso (2012: 3) adalah dapat menjalankan semaksimal mungkin fungsi pengembangan pendidikan yang meliputi perancangan, evaluasi, pemilihan, pemanfaatan, dan penyebarluasan, serta fungsi pengelolaan pendidikan, yang meliputi pengelolaan organisasi dan pengelolaan personel.

Kemampuan guru mengajar tentunya memberikan dampak terhadap aspek kualitas kegiatan proses pembelajarannya. Hal ini sesuai dengan pendapat James dan Dahl (dalam Salamah, 2004) bahwa penguasaan materi seorang guru sangat berpengaruh dalam meningkatkan pengajaran yang berkualitas. Permasalahan yang menyangkut komponen guru dalam proses pembelajaran, kalau betul-betul dianalisis sangat terkait dengan fungsi manajemen dan fungsi pengembangan pengajaran dalam meningkatkan kualitas dan peranan guru dalam mengefektifkan proses pembelajaran, serta dapat memberi sumbangan pemikiran dalam mengantisipasi proses pembelajaran yang dilakukan oleh guru di sekolah.

Permasalahan yang akan diteliti dapat dirumuskan sebagai berikut. (1) apakah terdapat hubungan antara konsep diri dengan kemampuan mengajar guru di SMP Negeri di Kota Palangka Raya?; (2) apakah ada hubungan antara sikap guru terhadap pekerjaan dengan kemampuan mengajar guru di SMP Negeri di Kota Palangka Raya?; (3) apakah ada hubungan antara pengalaman menjadi guru dengan kemampuan mengajar guru di lingkungan di SMP Negeri di Kota Palangka Raya?; (4) apakah ada hubungan antara konsep diri, sikap guru terhadap pekerjaan, dan pengalaman menjadi guru, secara bersamasama dengan kemampuan mengajar guru di SMP Negeri di kota Palangka Raya? (5) apakah ada perbedaan hubungan diantara variabel konsep diri, sikap guru terhadap pekerjaan dan pengalaman menjadi guru dengan kemampuan 
mengajar guru di SMP Negeri di Kota Palangka Raya?

Adapun tujuan penelitian ini adalah untuk mendeskripsikan hubungan konsep diri dengan kemampuan mengajar guru, untuk mengetahui hubungan Sikap guru terhadap pekerjaan dengan kemampuan mengajar guru, untuk mengetahui hubungan pengalaman menjadi guru dengan kemampuan mengajar guru, untuk mengetahui hubungan antara konsep diri, sikap guru terhadap pekerjaan, dan pengalaman menjadi guru, dengan kemampuan mengajar guru, untuk mengetahui adanya perbedaan hubungan yang positif dan signifikan antara konsep diri, sikap guru terhadap pekerjaan, pengalaman menjadi guru, dengan kemampuan mengajar guru di SMP Negeri di Kota Palangka Raya.

Robbins (dalam Salamah, 2004) kemampuan merujuk ke suatu kompetensi seseorang untuk mengerjakan berbagai tugas dalam suatu pekerjaan tertentu. Sedangkan menurut Broke dan Stone kemampuan merupakan gambaran hakikat kualitatif dari perilaku yang rasional untuk mencapai tujuan yang diprasyaratkan dengan kondisi yang diharapkan. Kompetensi dapat diperlihatkan seseorang dengan cara atau bentuk kemampuannya dalam menyelesaikan tugas yang berhubungan dengan materi matakuliah tertentu. Berkaitan dengan kemampuan mengajar, Smith (dalam Salamah, 2004) menyatakan mengajar merupakan semacam kegiatan intensional atau yang disengaja dan kegiatan yang bersifat normatif. Kemampuan di sini dititikberatkan pada tugas guru dalam mengajar. Menurut Conners terdapat tiga tahapan tugas mengajar, yaitu: (1) sebelum pengajaran, (2) pelaksanaan pengajaran, dan (3) sesudah pengajaran (Hasibuan dan Mudjiono, 2013: 38-42). Pertama, sebelum pengajaran, berkenaan dengan (a) perumusan tujuan pengajaran, (b) pemilihan metode, (c) pemilihan pengalaman mengajar, (d) pemilihan bahan pelajaran, peralatan, dan fasilitas belajar, (e) cara membuka, pengembangan dan menutup pengajaran, (f) peranan dan pengelompokan peserta didik. Kedua, pelaksanaan pengajaran, meliputi: (a) pengelolaan kelas dan pengendalian kelas, (b) penyampaian informasi, keterampilan, dan proses, (c) penggunaan tingkah laku verbal, (d) penggunaan tingkah laku non verbal, (e) cara mendapatkan balikan, (f) prinsip-prinsip psikologi, (g) diagnosis kesulitan belajar; dan (h) evaluasi kegiatan interaksi. Ketiga, sesudah pengajaran, berkenaan dengan (a) penilaian pekerjaan siswa, (b) perencanaan pertemuan berikutnya, dan (c) penilaian kembali kegiatan belajar mengajar yang telah dilakukan. Kemampuan merencanakan kegiatan pengajaran adalah kegiatan yang dilakukan terlebih dahulu sebelum kegiatan pengajaran dimulai. Kemampuan pengajar dalam merencanakan kegiatan pengajaran meliputi: memahami tujuan pengajaran, mengidentifikasi topik-topik pelajaran dan menetapkan tujuan umum untuk semua topik, mengenali karakteristik peserta didik, membuat tujuan pengajaran menjadi spesifik dalam bentuk tingkah laku peserta didik, mengenali subyek dan isi setiap materi, mengembangkan alat ukur, menyaring kegiatan belajar mengajar beserta sumbersumbernya, serta mengembangkan alat evaluasi hasil belajar. 
Adapun kemampuan mengajar meliputi dua tahap tugas, yaitu: tahap perencanaan dan pelaksanaan pengajaran, dengan indikatorindikator sebagai berikut. Pertama, merencanakan pengajaran, meliputi: merumuskan kompetensi dasar dan merumuskan indikator; mengembangkan dan mengorganisasikan materi; menentukan dan mengembangkan alat bantu (media); memilih sumber belajar, menyusun langkah-langkah pengajaran; dan membuat alat evaluasi, menentukan kunci jawaban, dan bobot penilaian. Kedua, melaksanakan pengajaran, meliputi: memulai kegiatan; menggunakan metode pengajaran; menggunakan alat bantu (media); melaksanakan kegiatan belajar dalam urutan yang logis; melaksanakan kegiatan belajar mengajar secara individual, kelompok, atau klasikal; mengelola waktu pengajaran secara efisien; memberi petunjuk dan penjelasan yang berkaitan dengan isi pelajaran; menanggapi pertanyaan dan respon peserta didik; menggunakan ekspresi lisan, tulisan, isyarat, dan gerakan tubuh; mendorong dan memelihara keterlibatan peserta didik; memantapkan penguasaan materi; menunjukkan kegairahan mengajar; membantu peserta didik menumbuhkan kepercayaan diri; menanamkan konsep dan mengembangkan materi yang sedang dipelajari; melaksanakan penilaian pada akhir pengajaran; menanggapi situasi kelas; mengakhiri pengajaran; dan memberikan tindak lanjut.

Konsep diri dapat didefinisikan secara umum sebagai keyakinan, pandangan atau penilaian seseorang terhadap dirinya (Rini, 2001: 1). Pendapat Carlson (1987: 586) tentang konsep diri adalah pandangan seseorang mengenai dirinya atau penilaian mengenai kepribadian dan kemampuan yang dimilikinya. Hal ini berarti konsep diri berkaitan dengan bagaimana seseorang melihat diri sebenarnya. Rakhmat (2009: 100-102) menyebutkan bahwa komponen konsep diri ada dua, yaitu komponen kognitif dan komponen afektif. Dalam psikologi sosial, komponen kognitif disebut citra diri (self image), sedangkan komponen afektif disebut penghargaan diri (self esteem). Konsep diri adalah persepsi dari fisik, sosial, dan psikologis dari diri kita yang kita turunkan dari pengalaman dan interaksi dengan orang lain. Konsep diri terbentuk karena adanya interaksi dengan orang lain. Konsep diri merupakan gabungan dari citra diri (apa yang dilihat seseorang ketika dia melihat pada dirinya sendiri), intensitas afektif (seberapa kuat seseorang merasakan tentang bermacammacam segi), evaluasi diri (apakah seseorang mempunyai pendapat menyenangkan/tidak menyenangkan tentang bermacam-macam segi dari image itu), dan apa yang kemungkinan besar diperbuat seseorang di dalam memberi respon kepada evaluasi dirinya sendiri. Dengan demikian, konsep diri adalah gambaran yang dimiliki seseorang tentang dirinya sendiri dan merupakan gabungan kenyakinan, aspirasi, dan prestasinya.

Berdasarkan beberapa pendapat tersebut, dapat disimpulkan bahwa konsep diri mencakup self esteem (penghargaan diri) dan ideal self (kelak menjadi apa diri kita), meliputi pandangan, perasaan, dan penilaian yang terakumulasi dalam persepsi seseorang mengenai kualitas psikologis, fisik, dan sosial yang dimilikinya. Konsep diri merupakan totalitas dari semua apa yang dapat dikatakan seseorang tentang dirinya. Pendapat lain Rini (2001: 1). Seseorang dikatakan mempunyai konsep diri negatif jika ia meyakini 
dan memandang bahwa dirinya lemah, tidak berdaya, tidak dapat berbuat apa-apa, tidak kompeten, gagal, malang, tidak menarik, tidak disukai dan kehilangan daya tarik terhadap hidup. Orang dengan konsep diri negatif akan cenderung bersikap pesimistik terhadap kehidupan dan kesempatan yang dihadapinya. Menurut Gunawan (2005: 3) Konsep diri yang jelek akan mengakibatkan rasa tidak percaya diri, tidak berani mencoba hal-hal baru, tidak berani mencoba hal yang menantang, takut gagal, takut sukses, merasa diri bodoh, rendah diri, merasa diri tidak berharga, merasa tidak layak untuk sukses, pesimis, dan masih banyak perilaku inferior lainnya. Konsep diri terbentuk melalui proses belajar sejak masa pertumbuhan seorang manusia dari kecil hingga dewasa. Lingkungan, pengalaman dan pola asuh orang tua turut memberikan pengaruh yang signifikan terhadap konsep diri yang terbentuk. Sikap atau respon orang tua dan lingkungan akan menjadi bahan informasi bagi anak untuk menilai siapa dirinya. Oleh sebab itu, seringkali anak-anak yang tumbuh dan dibesarkan dalam pola asuh yang keliru dan negatif, atau pun lingkungan yang kurang mendukung, cenderung mempunyai konsep diri yang negatif.

Berbagai faktor dapat mempengaruhi proses pembentukan konsep diri seseorang. Pertama, pola asuh orang tua. Pola asuh orang tua turut menjadi faktor signifikan dalam mempengaruhi konsep diri yang terbentuk. Sikap positif orang tua yang terbaca oleh anak, akan menumbuhkan konsep dan pemikiran yang positif serta sikap menghargai diri sendiri. Sikap negatif orang tua akan mengundang pertanyaan pada anak, dan menimbulkan asumsi bahwa dirinya tidak cukup berharga untuk dikasihi, untuk disayangi dan dihargai; dan semua itu akibat kekurangan yang ada padanya sehingga orang tua tidak sayang. Kedua, kegagalan. Kegagalan yang terus menerus dialami seringkali menimbulkan pertanyaan kepada diri sendiri dan berakhir dengan kesimpulan bahwa semua penyebabnya terletak pada kelemahan diri. Kegagalan membuat orang merasa dirinya tidak berguna. Ketiga, depresi. Orang yang sedang mengalami depresi akan mempunyai pemikiran yang cenderung negatif dalam memandang dan merespon segala sesuatunya, termasuk menilai diri sendiri. Segala situasi atau stimulus yang netral akan dipersepsi secara negatif. Misalnya, tidak diundang ke sebuah pesta, maka berpikir bahwa karena saya "miskin" maka saya tidak pantas diundang. Orang yang depresi sulit melihat apakah dirinya mampu survive menjalani kehidupan selanjutnya. Orang yang depresi akan menjadi super sensitif dan cenderung mudah tersinggung atau "termakan" ucapan orang. Keempat, kritik internal. Terkadang, mengkritik diri sendiri memang dibutuhkan untuk menyadarkan seseorang akan perbuatan yang telah dilakukan. Kritik terhadap diri sendiri sering berfungsi menjadi regulator atau rambu-rambu dalam bertindak dan berperilaku agar keberadaan kita diterima oleh masyarakat dan dapat beradaptasi dengan baik.

Sikap manusia diidentifikasi oleh para ahli dalam berbagai versi. Sikap merupakan bentuk evaluasi atau bentuk perasaan. Seperti yang duingkapkan oleh Azwar (2011:5) bahwa sikap merupakan tingkatan cendrung bersifat positif atau negatif yang berhubungan dengan objek psikologis. Objek psikologis meliputi symbol kata- 
kata, dengan orang atau lembaga ide. Pendapat selanjutnya bahwa sikap adalah suatu predisposisi keadaan mudah terpengaruh terhadap seseorang, ide, atau objek yang berisi komponen-komponen cohgnitive, affective, dan behavior (Dharmanesta, 1999: 163). Lebih lanjut dipertegas lagi oleh Kotler (2011: 232) sikap merupakan sesuatu yang dipelajari (bukan bawaan). Oleh karena itu sikap lebih mudah dibentuk, dikembangkan, dipengaruhi dan dicegah. Dalam pengertian lain, sikap merupakan disposisi atau keadaan mental di dalam jiwa atau diri seseorang untuk bereaksi terhadap lingkungannya (Koentjaraningrat, 2011: 26).

Sikap juga dikatakan sebagai suatu respon evaluatif (Azwar, 2011:15), artinya bahwa bentuik reaksi yang dikerjakan sebagai sikap itu timbulnya didasari oleh proses evaluasi dalam diri individu dan memberi simpulan terhadap stimulus dalam bentuk nilai-nilai baik buruk, positif negatif, menyenangkan dan tidak menyenangkan.

Para Ahli psikologi memberikan pengertian sikap secara berbeda-beda sesuai dengan sudut pandang mereka masing-masing. Ada tiga kelompok pemikiran menurut Azwar (2011: 4-5) Kelompok pertama mengartikan sikap sebagai suatu bentuk evaluasi atau reaksi perasaan terhadap sesuatu objek yang bersifat mendukung atau tidak mendukung. Kelompok kedua, mengartikan sikap sebagai kesiapan untuk bereaksi terhadap suatu objek dengan cara-cara tertentu. Sedangkan kelompok ketiga menyatakan bahwa sikap sebagai kontelasi komponen kognitif, afektif, dan konatif yang saling berinteraksi dalam memahami, merasakan dan berperilaku terhadap objek.
Berdasarkan pendapat para ahli tersebut, maka sikap guru terhadap pekerjaan merupakan keyakinan seorang guru mengenai pekerjaan yang diembannya, yang disertai adanya perasaan tertentu, dan memberikan dasar kepada guru tersebut untuk membuat respons atau berperilaku dalam cara tertentu sesuai pilihannya. Sikap guru terhadap pekerjaan berhubungan tingkat kepercayaan (trust), kepuasan (satisfaction), dan perilaku (behavior)guru dalam menjalankan aktivitas kerjanya. Dimensi sikap meliputi: kognitif, afektif, dan konasi, sedangkan aspek yang diukur mengenai (1) jabatan guru, (2) pelakasanaan tugas, (3) kode etik profesi, dan (4) organisasi profesi.

Leming (dalam Salamah, 2004) menyatakan bahwa pengalaman menjadi guru dapat diindikasikan dengan lamanya tahun mengajar, yaitu guru yang mempunyai pengalaman 10 tahun mengajar sebagai guru dalam posisi awal, pengalaman 15 tahun sebagai guru dalam posisi tengah, dan pengalaman mengajar lebih dari 20 tahun sebagai guru yang sudah ahli.

Hasil penghayatan situasi yang sebenarnya dan bereaksi dengan sungguh-sungguh terhadap berbagai aspek situasi untuk mencapai tujuan yang nyata. Hal ini seperti dikemukakan oleh Barnath (1980: 79) bahwa pengalaman adalah pengetahuan dan ketermpilan yang diperoleh seseorang melalui pelaksanaan suatu pekerjaan, melakukan pengamatan, atau menghayati situasisituasi yang sebenarnya.

Berliner (1994: 73-79) terdapat lima tahapan yang dialami guru untuk dapat dikatakan menjadi guru ahli, yaitu: (1) pemula, dengan pengalaman mengajar satu tahun pertama, (2) 
pemula lanjut, dengan pengalaman mengajar 2-3 tahun, (3) kompeten, dengan pengalaman mengajar 3-4 tahun, (4) cakap/pandai, dengan pengalaman mengajar 5 tahun, dan (5) ahli, dengan pengalaman mengajar 5 tahun ke atas. Dalam hal ini dapat dikatakan bahwa semakin lama seorang guru menekuni tugas mengajar, semakin tinggi penguasaan dalam melakukan tugas mengajar. Guru punya tanggung jawab profesional. Tanggung jawab guru dalam mengajar membutuhkan kompetensi profesional dan kompetensi personal yang kuat. Di lain pihak, keikutsertaan dalam seminar, penataran akan menambah pengetahuan untuk meningkatkan kemampuan mengajar. Berdasarkan uraian tersebut, yang dimaksud pengalaman mengajar dalam penelitian ini adalah lamanya seorang guru mengajar di Sekolah Menengah Pertama Negeri di Kota Palangka Raya.

\section{METODE}

Sesuai dengan tujuan penelitian, jenis penelitian ini dikategorikan sebagai penelitian survey. Menurut Sukardi (2012:193) penelitian survey merupakan kegiatan penelitian yang mengumpulkan data pada saat tertentu dengan tiga tujuan penting, yaitu: (1) mendeskripsikan keadaan alami yang hidup saat itu; (2) mengidentifikasi secara terukur keadaan sekarang untuk dibandingkan; dan (3) menentukan hubungan sesuatu yang hidup di antara kejadian spesifik. Pendekatan dalam penelitian ini adalah kuantitatif. Sifat dari penelitian ini adalah deskriptif dan korelasional. Penelitian bersifat deskriptif adalah suatu penelitian yang berupaya untuk memperoleh informasi yang berkaitan dengan fenomena yang diamati (Arikunto, 2012). Dalam penelitian ini berusaha untuk mendeskripsikan data pada Sekolah Dasar Negeri (SMPN) di Kota Palangka Raya. Sedangkan sifat korelasional dimaksudkan untuk menjelaskan hubungan atau korelasi antara berbagai variabel berdasarkan besar kecilnya koefisien korelasi (Ary, dkk, 2000; Sugiyono, 2014).

Subjek penelitian adalah guru-guru sekolah menengah pertama di Kota Palangka Raya. Populasi penelitian berjumlah 671 guru. Sampel ditentukan secara proporsional random sampling dengan jumlah sampel 362 orang guru. Instrumen utama dalam penelitian ini adalah angket atau kuesioner yang disusun sendiri oleh peneliti berdasarkan teori yang terdiri dari instrumen konsep diri, sikap guru terhadap pekerjaan, pengalaman menjadi guru dan kemampuan mengajar. Semua instrumen tersebut diisi oleh guru.

Teknik analisis data yang digunakan untuk menguji hipotesis penelitian yaitu statistik inferensial dengan bantuan program SPSS for windows. Namun, sebelum analisis statistik inferensial dilakukan, terlebih dahulu dilakukan uji asumsi yang terdiri atas uji normalitas, linieritas, multikolinieritas, dan homosedatisitas. Seluruh penghitungan uji asumsi juga dilakukan dengan bantuan SPSS. Hipotesis pertama, kedua, dan ketiga dianalisis dengan uji korelasi product moment dilanjutkan dengan uji $\mathrm{t}$ untuk melihat keeratan hubungan. Hal ini dilakukan kerena tujuan analisis hipotesis itu adalah untuk mengetahui hubungan atau korelasi. Hipotesis keempat diuji dengan menggunakan uji regresi berganda dengan tiga prediktor. Hal itu dilakukan 
karena tujuan analisis hipotesis keempat adalah untuk mengetahui korelasi secara bersama-sama variabel bebas $(X)$ pertama, kedua, ketiga dan keempat terhadap variabel terikat $(\mathrm{Y})$.

\section{HASIL DAN PEMBAHASAN}

Hasil penelitian dan pembahasan ini mengacu dengan permasalahan yang telah dirumuskan dengan bab 1 yakni ada 5 permasalahan yang akan dibahas berikut ini:

Masalah pertama mempertanyakan apakah ada hubungan konsep diri dengan kemampuan mengajar guru? Untuk menjawab permasalahan tersebut telah dilakukan pengujian hipotesis pertama untuk menyatakan bahwa ada hubungan yang signifikan konsep diri dengan kemampuan mengajar guru. Dari uji hipotesis dapat diketahui bahwa $\mathrm{rX}_{1 y}$ sebesar 0.599 dan koefisien determinasi parsial $R^{2}=0.359$ dengan $F$ hitung sebesar 20.689 dan Sig $F=0.000$, lebih kecil dari 0.05 , dan diperkuat lagi dari harga $t=4.548$ dan sig $\mathrm{t}=0.000<0.05$, (signifikan dengan taraf $5 \%$ ), hal ini berarti bahwa konsep diri memberikan hubungan yang signifikan dengan kemampuan mengajar guru. Konsep diri mampu memberikan sumbangan terhadap kemampuan mengajar guru sebesar $35.9 \%$. Dengan demikian maka konsep diri perlu diupayakan untuk selalu ditingkatkan dalam rangka meningkatkan kemampuan mengajar guru, sehingga guru dapat mengajar secara maksimal. Jika konsep diri yang dimiliki guru itu rata-rata tinggi maka dapat diprediksikan bahwa kemampuan mengajar guru juga akan tinggi (lebih meningkat).

Masalah kedua mempertanyakan apakah ada hubungan sikap guru terhadap pekerjaan dengan kemampuan mengajar guru? Untuk menjawab permasalahan tersebut telah dilakukan pengujian hipotesis kedua yang menyatakan bahwa ada hubungan yang signifikan sikap guru terhadap pekerjaan dengan kemampuan mengajar guru. Dari uji hipotesis diketahui bahwa $\mathrm{rx}_{2 y}$ sebesar 0.632 dan koefisien determinasi parsial $R^{2}=0.412$ dengan $F$ hitung sebesar 24.611 dan Sig $F=0.000$, lebih kecil dari 0.05 , dan diperkuat lagi dari harga $\mathrm{t}=4.961$, dan sig $\mathrm{t}=$ $0.000<0.05$ (signifikan dengan taraf $5 \%$ ), hal ini berarti bahwa sikap guru terhadap pekerjaan memberikan hubungan yang signifikan dengan kemampuan mengajar guru. Sikap guru terhadap pekerjaan mampu memberikan sumbangan terhadap kemampuan mengajar guru sebesar $41.2 \%$. Jika sikap guru terhadap pekerjaan yang dimiliki guru itu rata-rata tinggi maka dapat diprediksi bahwa kemampuan mengajar gurupun akan tinggi (lebih meningkat).

Sikap guru terhadap pekerjaan merupakan perwujudan dari kesadaran melaksanakan tugas, ketepatan dalam mengerjakan tugas, dan ketaatan dalam melaksanakan tugas, perlu selalu ditingkatkan sehingga guru dapat melaksanakan kegiatan belajar mengajar dengan baik, dan secara langsung akan meningkatkan kemampuan mengajar guru sehingga hasil belajar para peserta didik menjadi tinggi.

Masalah ketiga mempertanyakan apakah ada hubungan pengalaman menjadi guru dengan kemampuan mengajar guru? Untuk menjawab pertanyaan tersebut telah dilakukan pengujian hipotesis ketiga yang menyatakan bahwa ada hubungan yang signifikan pengalaman menjadi guru dengan kemampuan mengajar guru. Dari uji hipotesis diketahui bahwa $r_{3 y}$ sebesar 0.577 dan koefisien determinasi parsial $R^{2}=0.393$ dengan $F$ 
hitung sebesar 18.513 dan Sig $F=0.000$, lebih kecil dari 0.05 , dan diperkuat lagi dari harga $\mathrm{t}=$ 4.303 dan sig $t=0.000$ lebih kecil dari 0.05 , (signifikan dengan taraf 5\%), hal ini berarti bahwa pengalaman menjadi guru memberikan hubungan yang signifikan terhadap kemampuan mengajar guru. Pengalaman menjadi guru mampu menjelaskan kemampuan mengajar guru sebesar $39.3 \%$.

Pengalaman menjadi guru merupakan bagian yang sangat berpengaruh terhadap kemampuan mengajarnya. Karena itu guru yang senior dan telah berpengalaman dapat saja dimintai bantuannya untuk melakukan pembimbingan kedengan guru-guru yang masih yunior, misalnya dalam supervisi kunjungan kelas, kegiatan MGMP sekolah dan lain-lain kegiatan pengembangan guru.

Berdasarkan pengujian hipotesis keempat yang berbunyi ada hubungan yang signifikan konsep diri, sikap guru terhadap pekerjaan dan pengalaman menjadi guru, dan secara bersamasama dengan kemampuan mengajar guru diperoleh harga $F$ hitung $=16.286$, sig $F=0.0001$ lebih kecil dari 0.05 (signifikan dengan taraf $5 \%$ ) dan dengan harga $R^{2}=0.583$. ketiga variabel bebas tersebut secara bersama-sama memberi sumbangan yang signifikan dengan kemampuan mengajar guru khususnya dalam penelitian ini sebesar $58.3 \%$.

Apabila intensitas tingkat konsep diri diperoleh hasil yang tinggi maka dapat diprediksikan kemampuan mengajar guru akan tinggi. Demikian juga apabila tingkat sikap guru terhadap pekerjaan tinggi, maka dapat diprediksikan kemampuan mengajar gurupun akan tinggi, begitu juga untuk aspek pengalaman menjadi guru apabila tingkat pengalaman menjadi guru tinggi, maka dapat diprediksikan bahwa kemampuan mengajar gurupun akan tinggi.

Masalah kelima mempertanyakan apakah ada perbedaan hubungan diantara variabel konsep diri, sikap guru terhadap pekerjaan dan pengalaman menjadi guru dengan kemampuan mengajar guru. Untuk menjawab pertanyaan tersebut telah dilakukan pengujian hipotesis kelima yang menyatakan bahwa ada perbedaan hubungan antara variabel konsep diri, variabel sikap terhadap profesi guru, dan pengalaman menjadi guru. Berdasarkan hasil perhitungan analisis parsial dari masing-masing variabel $X_{1}$, $\mathrm{X}_{2}, \mathrm{X}_{3}$, terhadap $\mathrm{Y}$, diperoleh harga koefisien korelasi parsial, $\mathrm{rx}_{1 y}$ sebesar 0.599 dengan koefisien determinasi parsial $R^{2}=0.359$ berarti $X_{1}$ mampu memberikan sumbangan terhadap kemampuan mengajar guru sebesar $35.9 \%$, rx $\mathrm{ry}_{2 y}$ sebesar 0.632 dan koefisien determinasi parsial $\mathrm{R}^{2}=0.412$ berarti $\mathrm{X}_{2}$ mampu memberikan sumbangan terhadap kemampuan mengajar guru sebesar $41.2 \%, r_{3 y}$ sebesar 0.577 dan koefisien determinasi parsial $R^{2}=0.393$ berarti $X_{3}$ mampu memberikan sumbangan terhadap kemampuan mengajar guru sebesar $39.3 \%$, Hal ini berarti hipotesis nihil di tolak dan hipotesis kerja diterima. Berdasarkan besarnya sumbangan dari masing variabel sebagaimana diuraikan di atas, dapat di urutkan dari sumbangan yang terbesar; yaitu variabel sikap guru terhadap pekerjaan (41.2\%), variabel pengalaman menjadi guru (39.3\%), variabel konsep diri guru (35.9 \%), Dengan demikian dapat diartikan bahwa variabel sikap gur terhadap pekerjaan (41.2\%), merupakan variabel yang paling dominan hubungannya terhadap kemampuan mengajar guru. Ini berarti untuk 
meningkatkan kemampuan mengajar guru, kepala sekolah perlu meningkatkan adanya sikap positif guru terhadap pekerjaan, dengan berbagai upaya, baik secara langsung maupun secara tidak langsung. Secara langsung misalnya dengan meningkatkan pengawasan, memberikan pelayanan sesuai kebutuhan guru, memberikan keteladanan, dan secara tidak langsung misalnya dengan memberikan sanjungan, bombongan terhadap guru yang telah mampu mengajar dengan baik dan memberikan bimbingan tehnis dan pedagogis kedengan guru yang belum mampu mengajar dengan baik.

\section{KESIMPULAN DAN SARAN}

\section{Kesimpulan}

Dari hasil analisis data dan pembahasan yang telah dilakukan, maka dapat diambil kesimpulan sebagai berikut.

1. Ada hubungan konsep diri terhadap kemampuan mengajar guru di SMPN Kota Palangka Raya, konsep diri mampu memberikan sumbangan terhadap kemampuan mengajar guru sebesar $35.9 \%$.

2. Ada hubugan sikap guru terhadap pekerjaan dengan kemampuan mengajar guru di SMPN Kota Palangka Raya, hal ini berarti sikap guru terhadap pekerjaan memberikan sumbangan secara signifikan pada kemampuan mengajar guru.

3. Ada hubungan pengalaman menjadi guru terhadap kemampuan mengajar guru di SMPN Kota Palangka Raya, hal ini berarti pengalaman menjadi guru memberikan sumbangan secara signifikan kemampuan mengajar guru.
4. Ada hubungan variabel konsep diri, sikap guru terhadap pekerjaan dan pengalaman menjadi guru, secara bersama-sama terhadap variabel kemampuan mengajar guru.

5. Ada perbedaan hubungan diantara variabel konsep diri, sikap guru terhadap pekerjaan dan pengalaman menjadi guru dengan kemampuan mengajar guru. Variabel sikap guru terhadap pekerjaan (41.2\%), merupakan variabel yang paling dominan hubungannya terhadap kemampuan mengajar guru.

\section{Saran}

Dari hasil penelitian menunjukkan bahwa konsep diri, sikap guru terhadap pekerjaan, pengalaman mengajar guru berhubungan secara signifikan dengan kemampuan mengajar guru. Berdasarkan hasil penelitian ini disarankan bahwa (1) kepala sekolah harus selalu melakukan pengawasan terhadap kemampuan mengajar guru, agar tercipta konsep diri, sikap guru terhadap pekerjaan berdasarkan pengalaman menjadi guru; (2) konsep diri dan sikap terhadap pekerjaan merupakan hal yang paling dominan, maka guru harus selalu meningkatkan konsep diri dan sikap terhadap pekerjaan demi meningkatnya kemampuan mengajar.

\section{DAFTAR PUSTAKA}

Arikunto, S. 2012. Prosedur Penelitian: Suatu Pendekatan Prantik. Jakarta: Reneka cipta.

Ary, D., Jacobs, L.C., \& Razavieh, A. 2000. Pengantar Peneiltian dalam Pendidikan. Alih Bahasa oleh Arief Furchan. Surabaya: Usaha Nasional 
Azwar, S. 2011. Sikap Manusia: Teori dan Pengukurannya. Yogyakarta: Liberty.

Barnath, R. W. 1980, The World Book Dictionary, Volume One A-K, Chicago: World Book

Berliner, D. 1994, Teaching Expertise: Teaching and Learning in the Primary School, London: Routledge

Carlson, N.R. 1987, Psichology: The Science of Behavior, Massachutts: Allyn and Bacon

Dharmanesta, B.S. 1999. Theory Planned Behavior dalam Penelitian Sikap. Review, No 18/VII/1999. Yogyakarta: Gajah Mada University Indonesia

Engkoswara, 2005, Menuju Indonesia Modern 2020, Bandung: Yayasan Amal Keluarga

Gunawan, A.W. 2005. Konsep Diri Positip: Kunci Keberhasilan Hidup. Dalam http://www. Jurnal Pendidikan_2_2. HUBU.com

Hasibuan, JJ, \& Mudjiono, 2013, Proses Belajar Mengajar, Bandung: PT Remaja Rosdakarya

Kasinu, A. 2006, Mewujudkan SDM Berkualitas Melalui Perubahan peran dan Wawasan Guru, Jurnal, INOVASI, Vol 1, No. 2 Juni 2006

Koentjaraningrat, 2011. Kebudayaan Mentalitas dan Pembangunan. Jakarta: PT Gramedia.

Kotler, P. 2011. Manajemen Marketing. New Jersey: Prentice Hall.

Miarso, Y., dkk, 2012, Definisi teknologi Pendidikan, Jakarta: CV Rajawali

Morgan, C.T, et al, 1989, Instruction to Psychology, New York: John Wiley and Sons Inc.

Rahmad, J. 2009, Psikologi Komunikasi, Bandung: Remaja Rosdakarya

Rini, J. J. 2001. Konsep Diri. Dalam http://www. Jurnal Pendidikan_2_2. HUBU.com
Salamah, 2004, "Kemampuan Mengajar Guru Sekolah Dasar," dalam Jurnal Teknologi Pendidikan Vol 6 No 1 April 2004

Sugiyono. 2014. Statistika Untuk Penelitian, Bandung: CV. Alfabeta.

Sukardi. 2012. Metodologi Penelitian Pendidikan: Kompetensi dan Praktiknya. Jakatra: Bumi Aksara. 